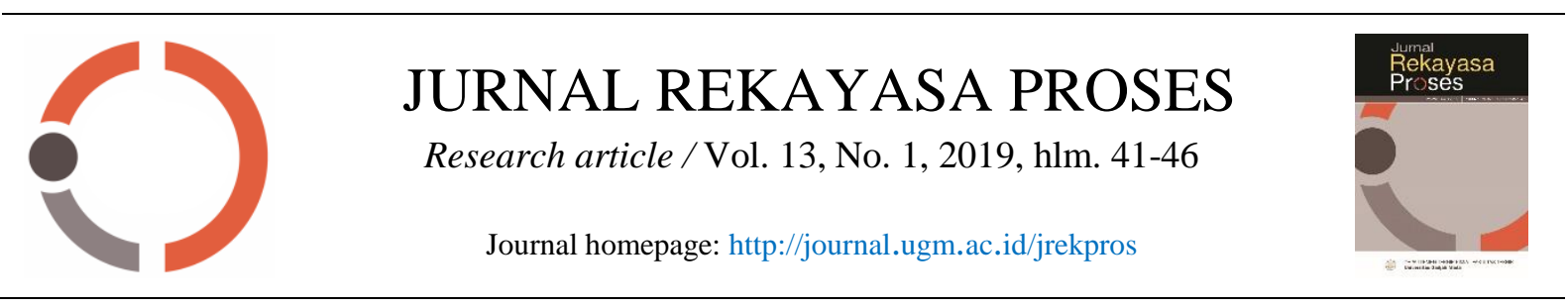

\title{
Penurunan Logam Hg dalam Air Menggunakan Sistem Sub-Surface Flow Constructed Wetland: Studi Efektivitas
}

\author{
Rikhanatul Firdausy Puspitasari*, Agus Prasetya, dan Edia Rahayuningsih \\ Departemen Teknik Kimia, Fakultas Teknik, Universitas Gadjah Mada \\ Jl Grafika No. 2 Kampus UGM, 55281 Yogyakarta \\ *Alamat korespondensi : puspitasarifirda20@gmail.com
}

(Submisi: 2 Oktober 2018; Revisi: 27 Februari 2019; Penerimaan: 3 Maret 2019)

\section{A B S T R A C T}

High amount of Mercury contamination is commonly found in traditional gold mining areas. This problem might occur due to the use of amalgamation process in traditional gold extraction process by dissolving the gold-bearing rocks with mercury $(\mathrm{Hg})$. The utilization of mercury in gold mining activity has contaminated the water with $\mathrm{Hg}$ which might lead to serious health problems. This research was carried out by discharging the Hg-contaminated wastewater to enter a system called the Sub-Surface Flow Constructed Wetland (SSF-SW). The system employed a mixture of soil and the fibers of water hyacinth as the media on which Echinodorus palaefolius $L$. was planted. The wastewater containing $\mathrm{HgCl}_{2}$ at $8.59 \mathrm{mg} / \mathrm{L}$ was flown. The flow rate and $\mathrm{pH}$ were set to $6.3 \mathrm{~L} /$ hour and 6-7 $\mathrm{pH}$ at room temperature. Samples were collected at $0 ; 3.5 ; 7 ; 10.5$ hours every day. The SSF-CW system was continually run for 10.5 hours and 13.5 hour batch. The result of this research showed that the efficiency of $\mathrm{Hg}$ removal reached $92.79 \%$. The results showed that the SSF-CW offers a stable system to reduce the mercury levels as shown in the growth of the plant and the total Hg removal efficiency. Plants with $\mathrm{Hg}$ exposure have distinct patterns of chlorosis. Some leaves turning yellow and die, others start with new growth. In addition, the growth of Echinodorus palaefolius L. was also influenced by the amount of nutrients in the soil.

Keywords: Echinodorus palaefolius L., mercury, sub-surface flow constructed wetland

\section{A B S T R A K}

Pencemaran merkuri banyak ditemukan pada penambangan emas tradisional. Pada umumnya proses yang diterapkan dalam penambangan emas tradisional dalam ekstraksi emas adalah proses amalgamasi, yaitu dengan cara mencampur bijih emas dengan merkuri (Hg). Aktivitas penambangan dengan memanfaatkan $\mathrm{Hg}$ menyebabkan tercemarnya air dengan $\mathrm{Hg}$ yang dapat membahayakan kesehatan. Penelitian ini dilakukan dengan cara mengalirkan air limbah $\mathrm{Hg}$ ke dalam sistem SubSurface Flow Constructed Wetland (SSF-CW). Media yang digunakan berupa campuran tanah dan serat eceng gondok serta ditanami dengan Echinodorus palaefolius L. Penelitian dilakukan dengan mengalirkan air limbah $\mathrm{HgCl}_{2}$ berkonsentrasi $8,59 \mathrm{mg} / \mathrm{L}$. Percobaan menggunakan laju alir 6,3 L/jam dengan $\mathrm{pH}$ sekitar 6-7 pada suhu ruangan. Pengambilan sampel dilakukan pada jam ke 0; 3,5; 7 dan 10,5 pada setiap harinya. Operasi sistem SSF-CW dijalankan 10,5 jam kontinu dan 13,5 jam batch. Hasil penelitian menunjukkan efisiensi penurunan $\mathrm{Hg}$ sebesar 92,79\%. Penelitian menunjukkan bahwa sistem SSF-CW cukup stabil. Kestabilan sistem SSF-CW dalam menurunkan kadar Hg dapat dilihat dari pertumbuhan tanaman dan total penurunan yang diperoleh. Tanaman yang terpapar $\mathrm{Hg}$ terlihat bercak klorosis. Beberapa daun menguning dan mati, sebagian lain tumbuh tunas baru. Pertumbuhaan Echinodorus palaefolius $L$. tidak lepas dari pengaruh unsur hara yang terdapat di dalam tanah.

Kata kunci: Echinodorus palaefolius L., merkuri, sub-surface flow constructed wetland 


\section{Pendahuluan}

Kegiatan penambangan di Indonesia telah menjadi bagian yang tidak dapat terpisahkan. Hal ini dikarenakan Indonesia memiliki lahan pertambangan yang terdapat di berbagai daerah. Salah satu bahan tambang yang banyak tersebar ketersediaanya di Indonesia adalah emas. Banyaknya lahan penambangan menimbulkan munculnya kegiatan penambangan emas secara liar. Kegiatan penambangan yang dilakukan di daerah-daerah biasanya dilakukan secara tradisional menggunakan proses amalgamasi. Amalgamasi merupakan proses ekstraksi emas dengan cara mencampur bijih emas dengan merkuri (Hg). Berdasarkan Harian Kompas (2017), salah satu daerah yang menggunakan merkuri dalam menambang emas terdapat di Aceh. Di Aceh Jaya terdapat 800 lubang tambang aktif dioperasikan dan memanfaatkan 192 ton merkuri. Kegiatan penambangan ini menyebabkan tercemarnya air yang berasal dari penggunaan merkuri, serta menimbulkan efek yang membahayakan bagi kesehatan. Paparannya menginfiltrasi jaringan dalam tubuh, merusak saraf, organ tubuh, dan otak, serta mengakibatkan janin cacat, keguguran, mutasi genetika, juga kematian

Sistem SSF-CW yang diteliti menggunakan tanaman melati air sebagai tanaman fitoremediator, yaitu tanaman yang dapat menjerap bahan pencemar. Peristiwa-peristiwa terdahulu menunjukkan bahwa tanaman melati air mampu menurunkan kadar fosfat limbah cair laundry (Siswandari, 2016). Selain itu melati air juga mampu menyerap logam $\mathrm{Cu}, \mathrm{Fe}, \mathrm{Zn}$ (Wibowo, 2014) dan $\mathrm{Pb}$ (Caroline dan Moa, 2015). Sebenarnya, semua tanaman mampu menyerap logam dalam jumlah yang bervariasi, tetapi beberapa tumbuhan mampu mengakumulasi unsur logam tertentu dalam konsentrasi yang cukup tinggi (Rondonuwu, 2014)

Tujuan penelitian ini adalah untuk mengetahui efektivitas dan stabilitas sistem sub-surface flow constructed wetland yang mengombinasikan antara media tanam berupa campuran tanah dan serat eceng gondok dengan tanaman melati air untuk menurunkan konsentrasi logam berat $\mathrm{Hg}$ pada air limbah. Constructed wetland merupakan sistem pengolahan terencana atau terkontrol yang telah didesain dan dibangun menggunakan proses alami yang melibatkan vegetasi, media, dan mikroorganisme untuk mengolah air limbah (Sutyasmi dan Susanto, 2013). Tingkat efisiensi penurunan konsentrasi $\mathrm{Hg}$ menggunakan sistem sub-surface flow constructed wetland yang dihasilkan dapat mencapai 99,8\% (Ambarsari dan Qisthi, 2017). Serat eceng gondok sebelumnya telah digunakan sebagai adsorben untuk mengurangi kadar $\mathrm{Pb}$ (Tangio, 2013) dan $\mathrm{Cu}$ (Hadiwibowo, 2008). Penelitian dilakukan pada pH 6-7. Adsorpsi yang paling baik terjadi pada pH 4 sampai 6, karena pada rentang sini sudah banyak situs aktif yang terdeprotonasi, pada $\mathrm{pH}$ di atas 6 adsorpsi merkuri berkurang karena keadaan merkuri telah mengendap menjadi $\mathrm{HgO}$ (Al-Ayubi dkk., 2010).

\section{Metode Penelitian}

\subsection{Bahan penelitian}

Bahan yang digunakan dalam penelitian ini adalah air limbah merkuri yang diencerkan dari $\mathrm{HgCl}_{2}$ p.a Emsure (Merck) dengan konsentrasi $8,59 \mathrm{mg} / \mathrm{L}$. Tanaman yang digunakan sebagai fitoremediator adalah 2 tanaman melati air (Echinodorus palaefolius) segar yang bebas hama. Biosorben yang digunakan sebagai campuran media tanam adalah tanaman eceng gondok segar yang kemudian dikeringkan, dihaluskan dan diayak menggunakan ayakan 10 mesh. Serat eceng gondok yang digunakan adalah sebanyak 500 gram. Media tanam yang digunakan adalah tanah humus yang diperoleh di area persawahan yang terletak di Desa Geneng, Sewon, Bantul, Yogyakarta.

\subsection{Cara Penelitian}

Percobaan dilakukan dalam sistem SSF-CW skala laboratorium berukuran $81 \mathrm{~cm}$ x $31,5 \mathrm{~cm}$ x $58,5 \mathrm{~cm}$. Instalasi SSF-CW terdiri dari 3 ruang, yaitu ruang influent, ruang operasi, dan ruang effluent. Limbah $\mathrm{HgCl}_{2}$ buatan dimasukkan ke dalam alat menggunakan pompa. Dalam percobaan ini, air dibiarkan mengalir dari ruang 
influent ke dalam ruang adsorpsi dari lubang lubang kecil yang terdapat pada sekat antara ruang influent dan ruang operasi.

Sebelum dilakukan operasi dengan menggunakan limbah $\mathrm{HgCl}_{2}$ buatan, proses diawali dengan aklimatisasi tanaman selama 28 hari untuk menyesuaikan tanaman terhadap lingkungan baru tempat hidupnya. Selanjutnya adalah proses penurunan $\mathrm{Hg}$ yang dilakukan selama 3 hari. Penelitian yang dilakukan menggunakan 2 mode, yaitu mode kontinu selama 10,5 jam dan mode batch selama 13,5 jam. Percobaan dilakukan dengan menggunakan air limbah $\mathrm{HgCl}_{2}$ buatan dengan konsentrasi 8,59 $\mathrm{mg} / \mathrm{L}$, laju alir 6,3 L/jam dengan $\mathrm{pH}$ sekitar 6-7, tidak ada penambahan larutan pengontrol $\mathrm{pH}$ yang dilakukan pada suhu ruangan. Pengambilan sampel dilakukan pada jam ke 0; 3,5; 7 dan 10,5 pada setiap harinya. Total proses percobaan adalah selama 58,5 jam. Percobaan dilakukan dalam 2 mode:

1. Kontinu dengan flowrate $6,3 \mathrm{~L} / \mathrm{jam}$, sampling dilakukan pada jam ke $0 ; 3,5 ; 7$ dan 10,5.

2. Batch selama 13,5 jam. Pada saat batch, limbah $\mathrm{HgCl}_{2}$ berhenti dialirkan.

Sampel yang diperoleh kemudian diuji kadar merkurinya menggunakan mercury analyzer. Prinsip kerjanya sampel dipanaskan untuk mengubah senyawa merkuri dalam bentuk atomnya atau dinamakan atomisasi, kemudian atom tersebut akan ditangkap oleh amalgam sehingga yang tinggal hanya uap merkuri. Analisis pada instrumen dilakukan pada panjang gelombang 253,7 nm. Gas merkuri yang dihasilkan akan dilewatkan pada cell tube yang ditembakkan sinar cahaya dari lampu merkuri. Berikut ini adalah spesifikasi mercury analyzer (LPPT UGM, 2018) secara singkat:

1. Rentang pengukuran: $0,1 \mathrm{ppb}-10 \mathrm{ppb}$

2. Panjang gelombang: $253,7 \mathrm{~nm}$

3. Detektor: UV

4. Sensitivitas: $5 \mathrm{ng} / \mathrm{L}$ atau $0,05 \mathrm{ng}$ absolut.

Karakteristik pori dari media berpori yang digunakan dianalisis dengan metode analisis nitrogen sorpsi. Isotherm diperoleh pada rentang 0-1 atm sebagai dasar perhitungan luas permukaan, ukuran pori, dan volum pori.

\section{Hasil dan Pembahasan}

\subsection{Pengaruh Temperatur Roasting terhadap Pelarutan Emas}

Tanah dan serat eceng gondok diukur kadar merkurinya dengan Mercury analyzer serta luas permukaannya dengan metode analisis nitrogen sorpsi dimana luas permukaan dihitung dengan metode Brunauer-Emmett-Teller (BET). Hasil analisis karakteristik dapat dilihat pada Tabel 1.

Tabel 1. Karakteristik media berpori

\begin{tabular}{ccc}
\hline Parameter uji & Tanah & $\begin{array}{c}\text { Serat eceng } \\
\text { gondok }\end{array}$ \\
\hline Kadar merkuri, $\mathrm{mg} / \mathrm{kg}$ & 0,159 & 0,073 \\
Average pore size, $\mathrm{nm}$ & 3,473 & 24,320 \\
Luas permukaan, $\mathrm{m}^{2} / \mathrm{g}$ & 27,393 & 2,053 \\
\hline
\end{tabular}

Tanaman melati air diketahui volume porosnya dari hasil uji BET seperti yang tersaji pada Tabel 2.

Tabel 2. Volume media berpori

\begin{tabular}{cc}
\hline Media tanam & Volume pori $(\mathrm{cc} / \mathrm{g})$ \\
\hline Tanah & 0,082 \\
Serat eceng gondok & 0,008 \\
\hline
\end{tabular}

Hasil percobaan menunjukkan adanya penurunan kadar logam $\mathrm{Hg}$ yang signifikan. Penurunan kadar Hg ini dapat dilihat pada Tabel 3.

Tabel 3. Penurunan kadar merkuri selama proses kontinu

\begin{tabular}{ccc}
\hline Hari ke- & Jam ke- & $\begin{array}{c}\text { Konsentrasi effluent } \\
\left(\mathrm{C}_{\mathrm{e}}\right)(\mathrm{mg} / \mathrm{L})\end{array}$ \\
\hline \multirow{3}{*}{1} & 0 & 8,59 \\
& 3,5 & 1,81 \\
& 7 & 0,96 \\
& 10,5 & 0,7 \\
2 & 24 & 0,57 \\
& 27,5 & 0,33 \\
& 31 & 0,27 \\
& 34,5 & 0,16 \\
& 48 & 0,26 \\
& 51,5 & 0,06 \\
& 55 & 0,25 \\
& 58,5 & 0,13 \\
\hline
\end{tabular}

Persentase penurunan $\mathrm{Hg}$ di dalam sistem SSF-CW dari hasil pengujian menggunakan Mercury analyzer, diperoleh dengan mengolah data konsentrasi keluar yang tersaji pada Tabel 3. Penggunaan data konsentrasi keluar $\left(C_{\text {out }}\right)$ dalam penghitungan, dikarenakan penurunan kadar $\mathrm{Hg}$ 
diketahui dari selisih konsentrasi yang masuk dan konsentrasi yang keluar dari sistem SSF-CW, sehingga diperoleh persamaan orde 2 .

a. Hari pertama

$$
\mathrm{C}_{\text {out }}=-0,0422 \mathrm{t}^{2}+0,4793 \mathrm{t}+0,1626
$$

b. Hari kedua

$$
\mathrm{C}_{\text {out }}=0,0027 \mathrm{t}^{2}-0,0647 \mathrm{t}+0,5585
$$

c. Hari ketiga

$$
\mathrm{C}_{\text {out }}=0,0016 \mathrm{t}^{2}-0,0229 \mathrm{t}+0,225
$$

Persamaan (1), (2), (dan (3) adalah persamaan untuk hari ke-1, 2 dan 3 saat sistem dialiri limbah $\mathrm{HgCl}_{2}$. Persamaan tidak dibuat untuk 3 hari sekaligus dikarenakan proses tidak berjalan selama 24 jam, melainkan hanya 10,5 jam. Persentase penurunan $\mathrm{Hg}$ di dalam sistem SSFCW oleh tanaman melati air dan media (tanah dan serat eceng gondok) dihitung dengan menghitung total $\%$ penurunan pada saat proses kontinu dan batch. Persentase penurunan $\mathrm{Hg}$ dapat dilihat pada Tabel 4.

Tabel 4. Persentase penurunan $\mathrm{Hg}$

\begin{tabular}{ccc}
\hline Hari ke- & Jam ke- & removal $_{\text {kontinu }}(\%)$ \\
\hline & 0 & 0 \\
1 & 3,5 & 9,940 \\
& 7 & 19,056 \\
& 10,5 & 28,672 \\
& & \\
2 & 24 & 28,663 \\
& 27,5 & 39,081 \\
& 31 & 49,704 \\
& 34,5 & 60,448 \\
& 48 & \\
3 & 51,5 & 60,420 \\
& 55 & 71,177 \\
& 58,5 & 91,987 \\
\end{tabular}

Percobaan ini dapat menurunkan kadar $\mathrm{Hg}$ sebesar $92,79 \%$. Hasil ini melewati efisiensi SSFCW pada umumnya dalam mengolah limbah yang sebesar $80 \%$ (Tangahu dan Warmadewanthi, 2001) dan mendekati hasil penelitian yang dilakukan Ambarsari dan Qisthi (2017) yang dapat menurunkan konsentrasi $\mathrm{Hg}$ sebesar 99,60\%. Dari Tabel 4, kemudian data yeng diperoleh dimasukkan ke dalam kurva persentase penurunan $\mathrm{Hg}$, seperti yang tersaji pada Gambar 1, bagian berwarna hijau menunjukkan masa jeda.

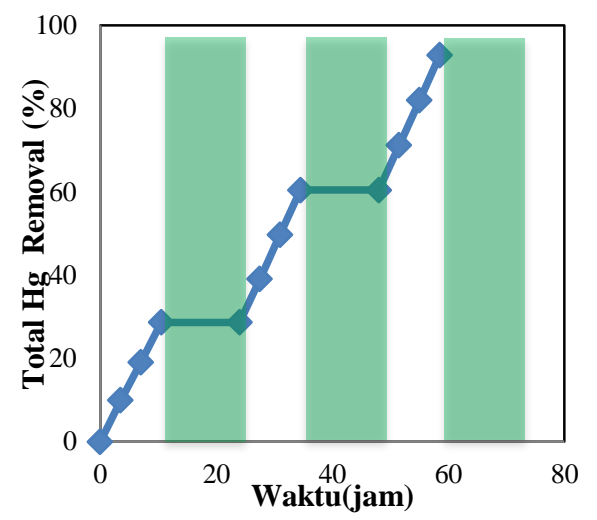

Gambar 1. Persentase penurunan ion $\mathrm{Hg}$ pada percobaan

Semakin lama operasi, kinerja sistem SSFCW menjadi menurun (Tabel 4 dan Gambar 1). Hal ini terjadi karena lambat laun biosorben mengalami kejenuhan sehingga menyebabkan semakin sedikit ion logam yang terjerap di dalam biosorben (Warisaura, 2018).

Percobaan diawali dengan proses aklimatisasi yang bertujuan untuk menyesuaikan kondisi tanaman di dalam sistem yang dibuat, seperti yang ditunjukkan pada Gambar 2.

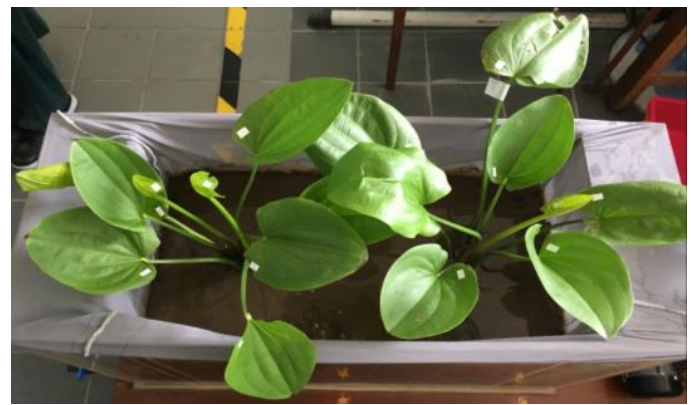

Gambar 2. Kondisi tanaman pada proses aklimatisasi

Saat percobaan berlangsung dengan dialiri $\mathrm{HgCl}_{2}$, pertumbuhanan tanaman melati air terhambat. Gambar 3 menunjukkan kondisi daun pada hari ke-2 percobaan. Beberapa daun terlihat mengalami klorosis dan nekrosis. Klorosis merupakan suatu peristiwa kerusakan pada daun karena diindikasikan adanya kegagalan dalam pembentukan klorofil pada daun. Sedangkan nekrosis merupakan gejala kematian jaringan tumbuhan terutama pada bagian daun. Klorosis dan nekrosis yang terjadi pada daun disebabkan 
karena efek toksisitas dari limbah sintetik $\mathrm{HgCl}_{2}$. Hal ini ditandai dengan timbul bercak coklat pada bagian pinggir dan tengah daun.

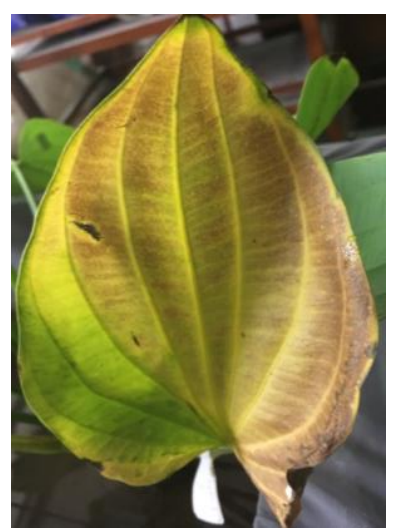

Gambar 3. Kondisi tanaman pada percobaan hari ke-2

Pada hari ke-3, beberapa daun menguning dan layu, seperti yang terlihat pada Gambar 4 .

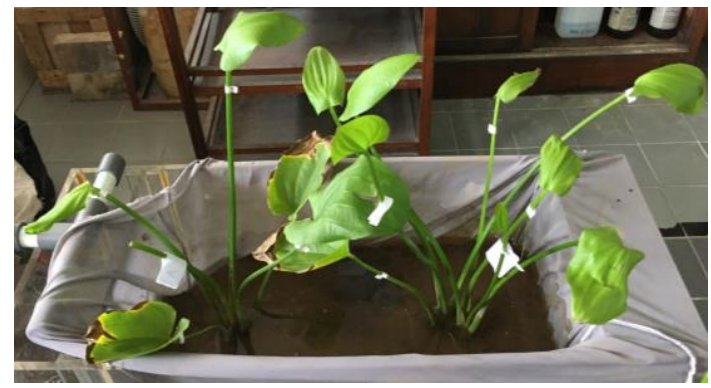

Gambar 4. Kondisi tanaman pada percobaan hari ke-3

Hal ini sesuai dengan penelitian yang dilakukan oleh Wang dan Zhou (2005) dalam Malar dkk. (2015), bahwa gejala keracunan $\mathrm{Hg}$ dapat menyebabkan klorosis, kering, atau bercak coklat pada daun, serta akar yang mengering. Pertumbuhan tanaman juga secara signifikan terpengaruh akibat paparan logam berat $\mathrm{Hg}$, sehingga dapat menyebabkan kematian pada tanaman.

\section{Kesimpulan}

Penurunan kadar merkuri pada percobaan jam ke-3,5 penurunan $\mathrm{Hg}$ pada hari pertama sebesar $28,66 \%$ dan terus meningkat hingga $92,79 \%$ pada jam 58,5. Dengan demikian, semakin bertambahnya waktu operasi, maka semakin besar pula penurunan kadar logam $\mathrm{Hg}$ dalam air. Penurunan logam merkuri menggunakan sistem sub-surface flow constructed wetland merupakan kombinasi antara media tanam berupa tanah yang dicampur serat eceng gondok dan ditanami tanaman melati air sangat efektif, karena dapat menurunkan kadar merkuri lebih dari $80 \%$. Fisiologi tanaman melati air terganggu akibat dialiri air limbah $\mathrm{HgCl}_{2}$. Hal ini ditandai dengan timbulnya bercak coklat pada beberapa bagian daun, tidak bertambahnya tinggi batang melati air, serta kematian pada beberapa batang. Namun, walaupun terdapat beberapa batang tanaman yang layu kemudian mati, tetapi terdapat tunas yang tumbuh. Hal ini menandakan bahwa tanaman dapat beradaptasi dengan baik pada sistem yang dibuat.

\section{Daftar Pustaka}

Al-Ayubi, M. C., Barroroh, H., dan Dewi, D. C., 2010, Studi keseimbangan adsorpsi merkuri (II) Pada biomassa daun eceng gondok (Eichhornia crassipes), ALCHEMY, 1 (2), 53-103.

Ambarsari, H., dan Qisthi, A., 2010, Remediasi merkuri $(\mathrm{Hg})$ pada air limbah tambang emas rakyat dengan metode lahan basah buatan terpadu, Jurnal Teknologi Lingkungan, 18 (2), 148-156.

Caroline, J., dan Moa, G. A., 2015, Fitoremediasi Logam Timbal $(\mathrm{Pb})$ Menggunakan Tanaman Melati Air (Echinodorus palaefolius) pada Limbah Industri Peleburan Tembaga dan Kuningan, Seminar Nasional Sains dan Teknologi Terapan III 2015, Institut Teknologi Adhi Tama Surabaya, 733-744.

Hadiwibowo, M., 2008, Penggunaan abu sekam padi sebagai adsorben dalam pengolahan air limbah yang mengandung logam $\mathrm{Cu}$, Teknik, 29 (1), 55-63.

Kompas, 2017, Harian Kompas. Dipetik 2018, dari Harian Kompas: https://kompas.id/ baca/utama/2017/11/13/merkuri-papar-jutaanwarga/ondonuwu.

Rondonuwu, S. B., 2014, Fitoremediasi limbah merkuri menggunakan tanaman dan sistem reaktor, Jurnal Ilmiah Sains, 14 (1), 52-59.

Malar, S., S. V. Sahi, P. J. C. Favas, and P. Venkatachalam., 2015, Assesmet of mercury 
heavy metal toxicity-induced psyiochemical and molecular changes in Sesbania grandiflora L., Int. j. Environ. Sci. Technol., 12, 3273-3282.

Siswandari, D., 2016, Echinodorus palaefolius sebagai tanaman fitoremedian dalam menurunkan phospat limbah cair laundry, SenasPro, 102-107.

Sutyasmi, S., dan Susanto, H. B., 2013, Penggunaan tanaman air (bambu air dan melati air) pada pengolahan air limbah penyamakan kulit untuk menurunkan beban pencemar dengan sistem wetland dan adsorpsi, Majalah Kulit, Karet, dan Plastik, 29 (2), 69-76.

Tangahu, B. V., dan Warmadewanthi, I. D., 2001, Pengelolaan limbah rumah tangga dengan memanfaatkan tanaman cattail (Typha angustifolia) dalam sistem constructed wetland, Purifikasi, 2 (3).

Tangio, J. S., 2013, Adsorpsi logam timbal (Pb) dengan menggunakan biomassa eceng gondok (Eichhornia crassipes), Jurnal Entropi, 8 (1), 500-506

Warisaura, A. D., 2018, Penurunan Kadar Merkuri pada Air Limbah Tambang Emas Rakyat dengan Kombinasi Metode Adsorpsi Zeolit dan Fitoremediasi Tanaman Melati Air pada Sub-Surface Flow Constructed Wetland (SSF-CW), Universitas Gadjah Mada, Yogyakarta

Wibowo, D., 2014, Penyisihan Logam pada Lindi dengan Sistem Sub-Surface Constructed Wetland, Program Studi Teknik Lingkungan, Universitas Tanjung Pura, Pontianak. 